\title{
Discussion on Green Financial Management of Enterprises in the \\ Context of Sustainable Development
}

\author{
Wu Lan, Liu Liu \\ School of Business, Sichuan University, Sichuan 610065, China; \\ School of Business, Sichuan University, Sichuan 610065, China; \\ WU.LAN110@163.com, job5027@163.com
}

Keywords: sustainable development, green financial management, problem, suggestion.

\begin{abstract}
With the rapid development of economy, the wasting of resource, environmental pollution and other issues have become increasingly serious. On this background, many countries and regions around the world have put forward the idea of sustainable development, it also forces enterprises to reflect on their business practices and determine whether they are opposite to the trend of social development. In the context of sustainable development, innovating the financial management which is the core of enterprise management is inevitable. This article sets force the significance of green financial management through explaining the concept of green financial management, comparing it with the traditional financial management, analysing the problems that the enterprises face during the course of implementing green financial management and offering proposals accordingly.
\end{abstract}

\section{Introduction}

As a crucial link in enterprise management, financial management's main obligation is to organize the financing, investment and allocation of profits appropriately, control the expenditure, and ensure the smooth process of the financial activities. [1] Maximizing profits is the central target in traditional enterprise management. However, with the deterioration of ecological environment and the generalizing of sustainable development strategy, the concept and model of traditional financial management can no longer fill the bills of environmental protection which is advocated by the society. The route of "develop first, govern later" is completely impracticable, green development has become a challenge for many enterprises to transform and realize sustainable development.

The Proposal of Conception of Green Financial Management Under the Concept of Sustainable Development

The definition of "sustainable development" can date back to the report named $<$ our common future $>$ which was composed by the World Commission on Environment and Development in 1987.The report defines it as: "A kind of development that fill the bills of the present without hazarding the development of future generations." In our country, as the economy continues to grow and its scale continues to expand, the use of resources, the consumption of energy, and the emission of wastes are all increasing, resources and environmental problems are increasingly severe. On the basis of practical exploration and theoretical research, environmental problems and sustainable development have become the themes of the party's literature and the party congress. Sustainable development which is one of the basic requirements of the Scientific Outlook on Development has become the focus of social attention in recent years. 
The demands of the age and the increasing strain on the worsening environment force us to change the extensive growth mode with high energy consumption and high pollution, get the best development with the minimum environmental cost. As a vital member of the organic system in society, the enterprises should fulfill their social responsibility, the notion of green financial management arises at the critical moment. The research on green finance management by Chinese scholars started in the 1990s and is still at the initial exploration phase. Existing studies have expounded the content of green financial management from diverse angles, but they all agree on the essence of it: Green financial management is a kind of financial management that comprehensively considers the limited resources, social benefits, environmental protection, and profitability of enterprises. Its purpose is to maximize the value of the enterprise while maintaining and improving ecological resources and environment, and realize the coordination and development of enterprises and society. [2]

\section{The Difference Between Green Financial Management and Traditional Financial Management}

"For profit" is an important point in the traditional definition of enterprise, as a result, the traditional financial management is based on the assumption of "Economic Person" [3]with profit maximization as it' s goal, therefore, the enterprises only consider economic efficiency in making operating decisions, that may bring about the short-term behavior while ignoring their own longterm development.

Green financial management is based on the assumption of "Social Person ". It combines the economic benefits of enterprises with ecological and social benefits, considers environmental issues at all stages of business operations, and undertakes more social responsibilities. Although it may affect the realization of the short-term financial goals when carrying out green financial management, in the long run, it creates space for sustainable development and greater profits for the enterprise.

\section{Problems in the Implementation of Green Financial Management}

Enterprises have weak awareness of green financial management. In the long-term development of our country, enterprises pay more attention to the economic, political, technological, and social environment during their operation. The traditional model of analyzing enterprises had never considered the ecological environment factor. The sustainable development has become a basic national policy in our country, even so, a large amount of enterprises still do not combine their own development with the environmental protection. There is insufficient comprehension of the essence and role of green development at the enterprise level, it hinders the implementation of green financial management.

Green financial management system is not consummate. The idea of green financial management has been proposed for many years, but its theoretical and application research are still insufficient. The theory and practice methods proposed by scholars did not form a complete theoretical system. In the meantime, there are no legible criteria and norms in the application of green financial management. In daily management, enterprises can only extract experience and methods from traditional financial management. Nevertheless, on account of the special essence of green financial management, these theories and methods are not sufficient to guide green financial management. The lack of operability and normalization is an actual problem. [4] 
The industry is short of corresponding supervision mechanisms. As things stand, the environmental protection agencies in our country can supervise the production and emission of the enterprises, but they cannot intervene the financial management of enterprises too much. The exiting accounting principles do not demand the enterprises to disclose the information about green accounting content. There is no clear oversight body for enterprises' green financial management. As a consequence, there is no rigid requirement for the implementation of green financial management in an enterprise, and it depends on self-consciousness.

\section{Solutions and Advices}

Enhance the cultivation of green financial management awareness. Bringing green financial management into effect may affect the short-term benefits of the enterprise. As a result, its resultful implementation asks the employees to understand and accept green financial management, and turn it into a self-awareness during their routine work. Enterprises should add green elements into the corporate culture and strengthen the promotion of green development when they train employees so that they will realize an actuality that the development of society in the future is a course of integration of politics, economy, and ecological environment. The continuous growth of enterprises is bound to face the benefit venture of green transformation. Enterprises should focus on the training of financial department staff so as to accelerate the implementation of green financial management,, which can help them establish the green financial management awareness, use green financial management to measure the use of resources in the operation of the enterprises, and use else valid financial methods to make up for it.

Complete the green financial management system. In the first place, it is of necessity to combine the theory and practice research of green financial management with a system of industryuniversity-research cooperation [5]to provide a practical operating standard for enterprises. Secondly, when raising funds, the enterprises must not merely consider the funds needed for routine business activities but also take environmental protection expenditures into account, which includes equipment purchase fees that can be used for green production and the treatment costs and fines that may caused by pollution. When making investment decisions, enterprises can take advantage of the government's policy support for green projects, and adequately consider whether the implementation of the investment plan will result in waste of resources, excessive waste discharge and other ecological problems in project evaluation and project construction. With respect to profit distribution, the enterprises can think about extracting the green welfare fund to provide guarantee for the implementation of the enterprises' green financial management. Finally, enterprises should carry out green accounting, and bring some new concepts such as green assets, green liabilities and green costs in. They can quantify the use of corporate resources from the perspective of sustainable development and combine ecological values with corporate assets.

simultaneously, the effect of the enterprise's green financial management implementation should be clarified in the notes of the financial statements.

Perfect the industrial criterion. The implementation of green financial management relies on industrial standards. As a result, it is of great importance to introduce an evaluation system for green financial management in the existing industry standards, and to promote the popularization and development of green financial management in enterprises by means of mandatory disclosure about green information. 


\section{The Significance of Green Financial Management Implementation.}

Carrying out green financial management is conductive to win the support of government for enterprises. China' s economy had been in urgent need of recovery since the reform and openingup. Researches on the economic development pattern are still not mature, policies and legal systems are not perfect too. The public also lack the awareness of sustainable development. Therefore, in order to obtain rapid development in a relatively short period of time and win further profits, many domestic enterprises adopt extensive and high-carbon, high-pollution developments that have caused irreparable damage to the environment. The environment is the foundation which all humans and society rely on to survive and develop. The increasingly severe environmental problems are not only detrimental to the sustainable development of enterprises, but also have a bad influence on people's lives. With the worsening ecological environment, sustainable development has become the focus of social concern. Since the 1990s, sustainable development has become a basic development strategy in China. The state has started calling for the construction of a resourcesaving and environment-friendly society. The government has also successively issued various policies to encourage green economy. Optimizing financial management models and implementing green financial management are requirements that meet the needs of the times. It can offer an opportunity for enterprises to enjoy the preferential government policies such as taxation and loans for the development of green economy.

The implementation of green financial management will contribute to the sustainable development of the enterprises, win favorable impression from the public and enhance market competitiveness. In the process of implementing green financial management, enterprises gradually achieve green development. It renders certain that the enterprise's external environment has been effectively maintained and helps enterprises to lay a good foundation for the sustainable development. Meanwhile, under the green financial management model, the public can learn about the economic benefits of the enterprise while catching sight of its specific influnce on the environment and the social obligations it bears, which helps the enterprise establish a good public impression and social reputation and finally win a place in the market competition.

\section{Summary}

Under the background of sustainable development, enterprises must transform traditional development models, update financial management idea in time, combine the long-term development of enterprises with the sustainable development of society, integrate green financial management goals with the enterprise's long-term goals, implement green accounting, carry out the idea of sustainable development in financial management links such as investment and financing, profit distribution, etc., take the protection of the ecological environment into account while promoting the growth of the enterprise's profits, and undertake more social responsibilities. 


\section{References}

[1] Qing Wenjie. Summary of Research on China's Green Finance Management [J]. Journal of Xiangtan University（Philosophy and Social Sciences）,2011(5).

[2] Liu Xianfeng ,Zeng Zhijun .On Enterprises' Implementation of Green Financial Management Mode Problems and Improvements[J]. Accounting Audit, 2016 (10).

[3] Wang Zhiwan, Zhang Ling. Problems and Countermeasures in Implementing the Green Financial Management Mode in China's Enterprises [J]. Modern Economic Information, 2016 (9).

[4] Xing Haixia. The Construction Approach and Practical Significance of Green Financial Management [J]. Financial Audit, 2017(5).

[5] Zhang Junbo. Analysis of Obstacles and Breakthroughs in the Implementation of Green Accounting [J]. The Speech Hall, 2017(4). 